\title{
Evaluation of Effects of Credit-Risk on Return on Assets of Commercial Banks in Nepal
}

\author{
Dr. Kapil Khanal \\ Associate Professor \\ Shankar Dev Campus, TU, Nepal \\ kapilkhana1848@gmail.com
}

\begin{abstract}
Introduction: The major cause of bank distress in Nepal is associated with poor credit management which results to decline in credit standing of the banks. The study adopts judgmental sampling techniques.

Objective: To analyze and evaluate the impact of credit-risk ratio on return on assets of commercial banks in Nepal.

Research design: Descriptive and exploratory research designs were used.

Methods and materials: Review of various articles and collection of secondary data through the websites of Nepal Rastra Bank.

Results and conclusion: It is found that there is inverse relationship between credit risk ratio and return on assets ratio. The findings provide sufficient evidence that credit risk management indicators impact significantly on commercial bank performance in Nepal.
\end{abstract}

Article type: Research Paper

Key words: Credit risk ratio, return on assets ratio, commercial banks, Bank performance, Nepal

\section{Introduction}

Commercial banks play a vital role in the financial resource allocation of countries. They channel funds from depositors to investors continuously. They can do so, if they generate necessary income to cover their operational cost they incur in the due course. In other words for sustainable intermediation function, banks need to be profitable. Beyond the intermediation function, the financial performance of banks has critical implications for economic growth of country.

Non-performing loan refers to those loans which are not paying its principle as well as interest in time or overdue more than three months. Therefore, it consists of substandard loan, Doubtful loan and bad loan. The Non-performing loan ratio indicated the relationship between non-performing loan and total loan. It measures the proportion of non-performing loan in total loan and advance. High non-performing loan ratio indicates that bank's assets are not doing well or the loan department is not so conscious while passing loan. Therefore, Lower ratio will be preferred regarding non-performing loan ratio.

Good financial performance rewards the shareholders for their investment. This, in turn, encourages additional investment and brings about economic growth. On the other hand, poor banking performance can lead to banking failure and crisis which have negative repercussions on the economic growth. By considering this fact, this study tries to analyze the impact of credit-risk ratio on return on assets of commercial banks in Nepal.

\section{Review of Literature}

Credit risk is broadly defined as the risk of financial loss arising from borrowers' failure to honor their contractual obligations. For banks, credit risk arises principally from lending activities but also may arise from various other activities where banks are exposed to the risk of counter party default, such as trading and capital market debtbased securities. The importance of the quality of bank loans portfolio stems from the fact that poor loans quality may affect bank performance in two ways. One way is through its direct impact on profitability. Miller and Noulas (1997) suggest that the higher the exposure to high-risk loans, the higher the accumulation of unpaid loans and 
the lower the profitability. Duca and McLaughlin (1990) using a sample of U S banks conclude that variations in bank profitability are largely attributable to variations in loan loss provisions as they find little difference between the net income of the sample banks after netting out loan loss provisions.

Theoretically, the greater the exposure to credit risk, the lower is the banks profits; a negative effect of the credit risk on the banks profitability is expected. On the other hand, the credit risk may positively affect the profitability. While Athanasoglou, et al., (2008) and Miller and Noulas (1997) find that the effect of the credit risk on the profitability is negative in the USA, Al-Haschimi (2007) finds a positive effect of credit risk on Sub-Saharan African profitability.

According to Cai and Anjan (2008), credit management is the most important function of the banking industry. It is the most risky and difficult and at the same time the most profitable function performed by banks. The main source of credit risk include, limited institutional capacity, inappropriate credit policies, volatile interest rates, poor management, inappropriate laws, low capital and liquidity levels, direct lending, massive licensing of banks, poor loan underwriting, laxity in credit assessment, poor lending practices, government interference and inadequate supervision by the relevant regulatory authorities (Kithinji, 2010).

Additionally, credit risk is a serious threat to the performance of banks which when unchecked may lead to the total collapse of banks while, liquidity risk also act as a snare to banks with an unsound risk assessment and control policy (Ejoh, Okpa \& Egbe,2014). Coyle(2000) is of the view that these two risks cannot be ignored as they both have considerable bearing on the performance and survival of banks. Further, Kolapo, Ayeni and Oke (2012) are of the view that credit facility is said to be performing if payment of both principal and interest are up to date in accordance with agreed repayment terms. They further explained that NPL represents credits which the banks perceive as possible loss of funds due to loan defaults which are classified into substandard, doubtful or lost. Furthermore, Felix and Claudine (2008) state that there are various indicators of measuring performance of a bank and they include: ROA, ROE, Earnings per Share (EPS) and Profit after Tax (PAT). To Olowe (2009), ROA is the ratio of net operating profit that a company earns from its business operations in a given period of time to the amount of the company's total assets while, ROE is the ratio of net income of a business during a year to its shareholders equity during that year. It is a measure of profitability of shareholders investments (Pandey, 2010).

Also, Afriyie and Akotey (2010) used panel regression model to estimate credit risk management and profitability of selected rural banks in Ghana fora period of five years $(2006-2010)$. The result showed a significant positive relationship between non-performing loans and profitability of rural banks while, capital adequacy ratio showed a positive but insignificant relationship. The study recommends that Bank of Ghana should tighten its control mechanisms of rural banks to stop the unfortunate trend in the rural banking industry. Furthermore, Kolapo et al.(2012) used panel model analysis to examine credit risk and performance of five commercial banks in Nigeria over the period, 2000 through 2010. The study revealed a negative relationship between NPL, LLP and profitability and a positive relationship between loan and advances and profitability. The study recommends that banks in Nigeria should enhance their capacity in credit analysis and loan administration while the regulatory authority should pay more attention to banks' compliance to relevant provisions of the Banks and Other Financial Institutions Act (2004) as amended and prudential guidelines. In a more recent study, Ogboi and Unuafe (2013) used panel data analysis to investigate credit risk management and capital Adequacy on financial performance of commercial banks in Nigeria for a period of six years $(2004-2009)$. The result showed that sound credit risk management and capital adequacy impacted positively on bank financial performance with the exception of loans and advances which was found to have a negative impact on the performance of the sampled banks. The authors recommended that Nigerian banks should strengthen credit risk management strategies by conducting rigorous credit appraisal before loan disbursement and drawdown.

Almost all the literature on evaluation of bank performance agrees on this negative correlation between the credit risks controlled using these two variables and profitability. Taking into account the fact that loan loss reserves are provided for from a direct charge to the income statement of a bank this negative impact of an increase in this ratio on banks' profit should not be surprising. However, in the context of the risk-return tradeoff postulated according to the portfolio risk theory such a negative relationship goes against the general principle that with a higher risk comes higher return. 


\section{Objectives of the study}

1. To compare and analyze the credit-risk ratio and credit-deposit ratio of all commercial banks in Nepal.

2. To evaluate the impact of credit-risk ratio and credit-deposit ratio on return on assets of commercial banks in Nepal.

\section{Methodology Used}

The population of the research study is all 27 commercial banks in Nepal of mid July, 2020. Basically, these banks are classified into three broad categories- government supported public banks, joint-ventures banks and private commercial banks. All types of banks are the area of concern. The financial information of all the banks is available for the year 2019 and 2020. Therefore, pooled regression is based on the data of 2019 and 2020.

This study includes all commercial banks established as per the NRB records at the end, 2020. All 27 banks were selected for analysis. The research is based on secondary data, which was gathered from the banks' annual reports and financial reports including profit and loss accounts and balance sheets via the internet (Nepal Rastra Bank's website), government papers and consultancy reports.

\section{Data analysis and findings}

\section{a. Credit Risk Ratio}

To mitigate risk in default of any loan and advance provided by banks, they should be maintained some provision according to the due date. Provisioning amount should maintain on the basis of classification of loan. Financial institutions have to be maintained the provision as per classification of loan. It measures the quality of assets in reference of loan and advances and contraction of profit as well. Quality of assets is decreases, when the credit of financial institutions diversifies in to non-performing assets (NPA). Such losses, from quality of assets, can be compensated by debiting the profit and can be harmonized the financial strength of those financial institutions.

\section{Table 1 : Credit risk ratio of commercial banks}

\begin{tabular}{|c|c|c|c|c|c|c|c|}
\hline Bank & 2019 & 2020 & Average & Bank & 2019 & 2020 & Average \\
\hline NBL & 5.60 & 5.70 & 5.70 & LAXMI & 1.20 & 1.40 & 1.30 \\
\hline RBB & 10.50 & 8.70 & 9.60 & NCCB & 1.40 & 2.00 & 1.70 \\
\hline NABIL & 2.40 & 2.90 & 2.70 & ADB/N & 14.20 & 13.10 & 13.60 \\
\hline NIBL & 1.50 & 2.00 & 1.70 & GLOBAL & 3.20 & 2.20 & 2.70 \\
\hline SCBN & 1.30 & 1.40 & 1.30 & CITIZEN & 1.90 & 2.00 & 2.00 \\
\hline HBL & 4.30 & 2.70 & 3.50 & PRIME & 1.20 & 1.50 & 1.40 \\
\hline NSBI & 1.70 & 1.20 & 1.40 & SUNRISE & 1.20 & 2.10 & 1.70 \\
\hline NBBL & 17.90 & 5.70 & 11.80 & NICASIA & 3.30 & 3.00 & 3.10 \\
\hline EBL & 1.90 & 1.90 & 1.90 & PRABHU & 2.30 & 2.00 & 2.10 \\
\hline $\mathrm{BOK}$ & 2.80 & 2.80 & 2.80 & CENTURY & 1.30 & 3.60 & 2.40 \\
\hline NMB & 4.30 & 3.10 & 3.70 & SANIMA & 1.40 & 2.40 & 1.90 \\
\hline CIVIL & 1.50 & 1.60 & 1.60 & MEGA & 1.20 & 1.00 & 1.10 \\
\hline SIDDHARTHA & 1.60 & 1.30 & 1.50 & & & & \\
\hline MBL & 2.10 & 2.80 & 2.50 & & & & \\
\hline KUMARI & 2.00 & 2.90 & 2.40 & & & & \\
\hline AVERAGE & & & & & 3.30 & 2.90 & 3.10 \\
\hline
\end{tabular}

Source: Annual Reports of Commercial Banks, 2019 and 2020

The combined mean of credit risk ratio of two years of all commercial banks comes 3.1. The banks which were having more than 3.1 are 7 banks and less than 3.1 are 20 banks. The average credit risk ratio was 3.3 in 2019 which dropped down to 2.9 in 2020. The numbers of banks above and below 3.3 in 2019 were 7 and 20 banks respectively. There were 7 and 20 banks which had above and below 2.9 in 2020 . The credit risk ratio for many of the commercial banks ranges from 1.0 to 3.0. The banks having more than 1.0 to 3.0 percent credit risk ratio 
were 20.

The credit risk ratio of NBBL had drastically decreased from 17.9 in 2019 to 5.7 in 2020. Similarly, the credit risk ratio of CENTURY had drastically increased from 1.3 in 2019 to 3.6 in 2020. All government-owned commercial banks had highest percent credit risk ratio on an average but all newly operating commercial banks had less than 3.1 percent credit risk ratio. Besides NBBL, all joint venture commercial banks had credit risk ratio between 1.3 to 3.5 percent.

\section{b. Return on Assets}

Return on assets (ROA) is an indicator of how profitable company's assets are in generating profit. The return on assets percentage shows how profitable a company's assets are in generating revenue. This number tells what the company can do with what it has, i.e. how many rupees of earnings they derive from each rupee of assets they control. It's a useful number for comparing competing companies in the same industry. The number will vary widely across different industries. Return on assets gives an indication of the capital intensity of the company, which will depend on the industry; companies that require large initial investments will generally have lower return on assets. ROAs over $5 \%$ are generally considered good.

Table 2: Return on assets of commercial banks

\begin{tabular}{|l|c|c|c|c|c|c|c|}
\hline Bank & 2019 & 2020 & \multicolumn{2}{l}{ Average } & \multicolumn{2}{l}{ Bank } & \multicolumn{2}{l}{2019} & 2020 & Average \\
\hline NBL & 0.69 & 0.67 & 0.68 & LAXMI & 1.69 & 1.32 & 1.51 \\
\hline RBB & 1.86 & 1.35 & 1.60 & NCCB & 1.19 & 0.98 & 1.09 \\
\hline NABIL & 2.07 & 2.41 & 2.24 & ADB/N & 2.41 & 2.35 & 2.38 \\
\hline NIBL & 2.06 & 1.89 & 1.97 & GLOBAL & 1.25 & 1.06 & 1.16 \\
\hline SCBN & 2.48 & 2.73 & 2.60 & CITIZEN & 1.78 & 1.70 & 1.74 \\
\hline HBL & 2.86 & 1.88 & 2.37 & PRIME & 1.65 & 1.21 & 1.43 \\
\hline NSBI & 0.97 & 0.80 & 0.88 & SUNRISE & 1.45 & 1.17 & 1.31 \\
\hline NBBL & 3.58 & 4.00 & 3.79 & NICASIA & 0.65 & 0.66 & 0.66 \\
\hline EBL & 1.99 & 1.93 & 1.96 & PRABHU & 0.84 & 1.03 & 0.93 \\
\hline BOK & 2.39 & 2.04 & 2.22 & CENTURY & 2.20 & 0.46 & 1.33 \\
\hline NMB & 1.43 & 0.99 & 1.21 & SANIMA & 1.00 & 0.30 & 0.65 \\
\hline CIVIL & 2.21 & 1.52 & 1.86 & MEGA & 0.66 & 0.57 & 0.61 \\
\hline SIDDHARTHA & 4.38 & 2.13 & 3.25 & & & & \\
\hline MBL & 0.03 & 0.04 & 0.04 & & & & \\
\hline KUMARI & 1.09 & 0.97 & 1.03 & & & & \\
\hline AVERAGE & & & & $\mathbf{1 . 6 0}$ & $\mathbf{1 . 3 1}$ & $\mathbf{1 . 4 6}$ \\
\hline
\end{tabular}

Source: Annual Reports of Commercial Banks, 2019 and 2020

While taking the mean value as reference, 14 banks have return on assets below the mean value whereas 13 banks have return on assets above mean. Similarly in 2020, the average return on assets of the banks is 1.31 where SANIMA has the lowest (0.3) and NBBL has the highest (4.0) return on assets. 14 banks have their return on assets below the mean value whereas 13 banks have return on assets above mean value. The overall average of return on assets of the two years is 1.46. The table shows that 14 banks have less than mean return on assets and 13 banks have more than mean values. The newly established banks (SANIMA, MEGA, PRABHU) have not been able to achieve that industrial average, having the return on assets less than 1 percent. Joint venture banks have more than two percent return on assets. The three public commercial banks: NBL, RBB and ADBN have $0.67,1.6$ and 2.38 percent return on assets respectively. Among them, ADB/N is performing well whereas NBL has the lowest return on assets and indicates poor earnings performance. Among six joint venture commercial banks, NBBB has the highest return on assets where as NSBI has the lowest return on assets on an average of two years. SCBN has consistent return on assets in two years. In private commercial banks, BOK has consistent return on assets although it is not the highest. The highest return on assets of 3.25 among private commercial banks is that of Siddhartha Bank. 
Table 3 : Regression equation of return on assets with credit-risk ratio

\begin{tabular}{|c|c|c|c|}
\hline ROA & $=\beta_{0}$ & $+\beta_{1}$ CRR & $+\ldots \ldots+$ et \\
\hline & $=184.53$ & $-0.54 C^{*} R^{*}$ & \\
\hline S.E. & $=(28.83)$ & $(0.12)$ & \\
\hline $\mathrm{t}$ & $=(6.40)$ & $(-4.37)$ & \\
\hline & $\mathrm{R}^{2}=0.64$ & $\mathrm{~F}(1,59)=15.78$ & \\
\hline \multicolumn{4}{|c|}{ Number of obs. $=60 \quad$ d.f. $=59$} \\
\hline
\end{tabular}

Where, $\mathrm{ROA}=$ Return on assets $\quad \mathrm{CRR}=$ Credit-risk ratio

Note: * Significant at 0.01 levels

The simple regression model is shown in table no.3. It is found that the explanatory power of the model in this study is reasonably high. The $\mathrm{R}^{2}$ is 0.64 indicating that $64 \%$ of variation in commercial banks' return on assets is explained by the variation in the risk-return ratio. The F statistic of this model is also statistically significant at 1 percent indicating the presence of regression. The sign of credit-risk ratio is also negative as per the expectation. It means negative impact of credit-risk ratio on the return on assets of commercial banks. The regression result shows that other things remaining the same, one percent point increase in the credit-risk ratio leads to decrease 0.54 percent point in the return on assets of commercial banks in Nepal.

\section{Conclusion}

Based on the results of the empirical analysis, bank-specific determinant, credit risk ratio is able to explain significant part of bank profitability in Nepal. All government-owned commercial banks had highest percent credit risk ratio on an average but all newly operating commercial banks had lowest percent credit risk ratio. Aforementioned data implies that less than fifty percent commercial banks have low return on assets in comparison to banking industrial return on assets. The regression result also confirms that a high credit risk ratio is adversely affecting profit of commercial banks in Nepal.

The general interest of stakeholders in the performance of banks in Nepal can largely be attributed to the role they play in mobilizing deposits from the surplus sector and channeling same to the deficit sector. However, inefficient credit management poses a great danger to the liquidity position of a bank to create assets. Consequently, effective and efficient credit risk management has become more critical given the recurring incidences of bank distress and failure not only in Nepal but across the globe. This study adds to the existing literature on the relationships among credit risk management indicators and bank performance. In the context of this study, sufficient evidences have emerged that credit risk management indicators impact significantly on the performance of Nepalese commercial banks as measured by return on assets

\section{REFERENCES}

Afriyie, H. O. \& Akotey, J. O. (2010). Credit Risk Management and Profitability of Selected

Rural Banks in Ghana.Unpublished Research Project.

Al-Hashimi, A. (2007). "Determinants of Bank Spreads in Sub-Saharan Africa", draft.

Athanasoglou, P. P., Brissimis, S. N., \& Delis, M. D. (2008). "Bank specific, industry specific and macroeconomic determinants of bank profitability". Journal of International Financial Markets, Institutions and Money 18(2), 121-136.

Cai, J. \& Anjan, V. T. (2008). Liquidity Risk, Credit Risk, and Interbank Competition, Working Paper

Coyle, B. (2000). Framework for Credit Risk Management, Chartered Institute of Bankers, United Kingdom.

Duca, J \& McLaughlin, M. M., (1990). "Developments affecting the profitability of Commercial banks". Federal Reserve Bulletin, 76(7), 477-499.

Ejoh, N. O., Okpa, I. B. \& Egbe, A. A. (2014). The Impact of Credit and Liquidity Risk Management on the 
Profitability of Deposits Money Banks in Nigeria. International Journal of Economics, Commerce \& Management, 2(9): 1-15.

Felix, T. T. \& Claudine, N. T. (2008). Bank Performance and Credit Management. Unpublished Master Dissertation in Finance, University of Skovde. Retrieved from http: //www.essays.se/essay/55d54c0bd4/.

Kolapo, T. F., Ayeni, R. K. \& Oke. M. O. (2012). Credit Risk and Commercial Banks' Performance in Nigeria: A Panel Model Approach. Australian Journal of Business \& Management Research, 2(2): 31-38.

Kithinji, A. M. (2010). Credit Risk Management and Profitability of Commercial Banks in Kenya. School of Business, Unpublished Research Project, University of Nairobi, Nairobi.

Miller, S. and A. Noulas (1997). "Portfolio Mix and Large-bank Profitability in the USA," Applied Economics, Vol. 29, 505-12.

Molyneux, P. and Thornton, J. (1992). "Determinants of European Bank Profitability: a Note”, Journal of Banking and Finance, Vol. 16, No. 6, pp. 1173-1178.

Ogboi, C. \& Unuafe, O. K. (2013). Impact of Credit Risk Management and Capital Adequacy on the Financial Performance of Commercial Banks in Nigeria. Journal of Emerging Issues in Economics, Finance \& Banking (JEIEFB), 2(3): 703-717.

Olowe, A. (2009). Financial Management. 2nd Edition, Lagos: Brierly Jones Nigeria Limited.

Olweny T, Shipho TM (2011). "Effects of banking sectrol factors on the profitability of commercial banks in Kenya". Econ. Finance. Rev., 1(5): 1-30.

Pandey, I. M. (2010). Financial Management, 10th Ed. New-Delhi India: Vikas Publishing House PVT Ltd.

Pasiouras, F., \& Kosmidou, K. (2007). "Factors influencing the profitability of domestic and foreign commercial banks in the European Union". Research in International Business and Finance 21, 222-237.

Staikouras, C.K., Wood, G.E. (2004).The Determinants of European Bank Profitability. International Business and Economics Research Journal, vol. 3, no. 6, pp. 57-68.

Zopounidis, C., Despotis, D.K., Stavropoulou, E. (1995). "Multi attributes evaluation of Greek banking performance", Applied Stochastic Models and Data Analysis, Vol. 11, No.1, pp.97-107. 